\title{
A Radioimmunoassay of Porcine Proinsulin C-Peptide Immunoreactivity
}

\author{
MASAharu HORINO, KatSUmasa KOBAYASHI \\ AND NoBumasa SUETSUGU \\ Third Department of Internal Medicine, \\ Yamaguchi University, School of Medicine, Ube, Yamaguchi
}

\begin{abstract}
Synopsis
Antiserum to porcine proinsulin was prepared in a guinea pig. Removal of crossreacting insulin antibodies was achieved by addition of excess porcine insulin. After such treatment, antiserum retained reactivity to porcine proinsulin but lost its ability to bind insulin. Displacement of labeled porcine proinsulin was not observed with $50 \mathrm{ng}$ or less of insulin. Both of the synthetic porcine proinsulin C-peptide analogue (62-formyllysine porcine proinsulin sequence 31-63) and the extracted porcine proinsulin C-peptide analogue (sequence 33-63) reacted approximately as well as porcine proinsulin on a molar basis. Cross-reactions between porcine glucagon and bovine proinsulin were not evident.

Almost 100 per cent recovery of added porcine proinsulin was noted from talctreated porcine sera. The coefficient of variance was 6.5 per cent at a level 10 times the sensitivity for the two assays, and maximum sensitivity of the assay was 20 picogram.

Assayed values were expressed as C-peptide immunoreactivity (CPR), since porcine proinsulin and porcine proinsulin $C$-peptide exist in peripheral blood, and moreover, porcine proinsulin intermediate forms might be exisist in peripheral blood.

Immunoreactivity of porcine proinsulin in unextracted peripheral blood was assayed in 3 pigs after intravenous glucose load as CPR. Plasma CPR levels at fasting, $30 \mathrm{~min}$, and $60 \mathrm{~min}$ after glucose load were from less than 0.2 to $0.4,1.65$, and less than 0.2 to $0.98 \mathrm{ng}$ per $\mathrm{m} l$, respectively.

A specific radioimmunoassay of porcine CPR in unextracted peripheral plasma has been described.
\end{abstract}

The existence of a larger protein precursor of insulin in human islet cell adenoma have been reported (Steiner and Oyer, 1967) and the name of "proinsulin" was suggested for this protein (Steiner et al., 1967). Soon afterward the amino acid sequences of porcine and bovine proinsulin were determined (Chance, 1967; Yip and Lin, 1967). The rapid convertion of proinsulin to insulin by treatment with trypsin were noted by above investigators and this process took place in the $\beta$-cell after synthesis of proinsulin (Sorenson et al., 1970; Grant, 1971). Although human, porcine and bovine insulin have similar features in their

Received for publication February 26, 1973 , structure, the proinsulin found in these species differs considerably, and such structural variations are reflected in a high degree of immunological specificity (Rubenstein et al., 1970). Thus, a homologous assay system was required for determination of the absolute levels of proinsulin.

A specific radioimmunoassay of C-peptide in human serum has been reported, utilizing rabbit anti-human C-peptide and labeled tyrosylated human C-peptide (Melani et al., 1970a). Serum C-peptide levels were determined after acid ethanol extraction and gel filtration. Moreover, existence of circulatory C-peptide was verified by these methods. The intermediate forms of proinsulin may exist in 
peripheral blood, since C-peptide was identified in the serum. Purified porcine proinsulin antisera reacted with split proinsulin $\left(\mathrm{Leu}_{54}{ }^{-}\right.$ Ala $_{55}$ bond split), desdipeptide proinsulin $\left(\operatorname{Lys}_{62}-\operatorname{Arg}_{63}\right.$ absent) and desnonapeptide proinsulin (nonapeptide $\left(\mathrm{B}_{55^{-6} 63}\right)$ absent), as well as porcine proinsulin almost identically (Chance, 1972), and also purified proinsulin antisera reacted with $\mathrm{C}$-peptide from their species as well as specific proinsulin on a molar basis (Rubenstein et al., 1970). Proinsulin intermediate forms can not be separated from each other by gel filtration. Thus the term of "C-peptide immunoreactivity" (CPR) was advised to describe the total concentration of these components determined by the assay system in unextracted human serum (Block et al., 1972a, b). Although methods for radioimmunoassay of bovine or porcine proinsulin in homologous systems were reported by several investigators (Yip and Logothetopoulos, 1969; Rubenstein et al., 1970; Stoll et al., 1970), sensitivities of their assay systems appeared unsuitable for determination of CPR levels in unextracted peripheral blood. A specific radioimmunoassay for porcine CPR in unextracted porcine plasma will be described in this report.

\section{Materials and Methods}

Purification of porcine proinsulin from porcine insulin has been reported elsewhere (Horino et al., 1972). The isolated porcine proinsulin was used for immunization, labeling, and as an assay standard for the porcine proinsulin radioimmunoassay.

Antisera to porcine proinsulin were prepared in guinea pigs by repeated immunization with $1 \mathrm{mg}$ of isolated porcine proinsulin in Freund complete adjuvant at intervals of 4 weeks. Totally, $8 \mathrm{mg}$ of porcine proinsulin per guinea pig were used. The animals were bled 10 days following the last injection. Polymerized porcine insulin was prepared by the reported method (Avarameas, 1969). Proinsulin free porcine insulin (Lilly, PJ 5589) or polymerized insulin was added to the antiserum at various concentrations and gently stirred for 5 hous at room temperature following by an additional 3 days of incubation at $5^{\circ} \mathrm{C}$. The reaction mixture was cen- trifuged for $30 \mathrm{~min}$ at $10,000 \mathrm{rpm}$ at $5^{\circ} \mathrm{C}$. The clear supernatant was collected and divided into small vials after appropriate dilution. These were kept forzen at $-18^{\circ} \mathrm{C}$ until use. Guinea pig anti-porcine proinsulin No. 2 was chosen for the radioimmunoassay following the removal of insulin antibodies and preliminary experiments.

The isolated porcine proinsulin was labeled with ${ }^{125} \mathrm{I}$ by the Chloramine $\mathrm{T}$ method (Hunter and Greenwood, 1962). The labeled porcine proinsulin was purified using a Sephadex G-200 column $(1.8 \times$ $40 \mathrm{~cm}, 0.01 \mathrm{M}$ Phosphate $-0.15 \mathrm{M} \mathrm{NaCl} \mathrm{pH}$ 7.4) after quick separation of labeled hormone from free ${ }^{125}$ I by a Sephadex G-50 column $(1.0 \times 17 \mathrm{~cm}$, same buffer used). Specific activities of labeled porcine proinsulin were estimated to be from 100 to $150 \mathrm{mc}$ per mg.

Radioimmunoassay for porcine proinsulin was performed by the double antibody method (Morgan and Lazarow, 1963). An EDTA-albumin buffer (pH $7.4 ; 1.0 \%$ BSA, 0.01 M EDTA) was used. The volume of the first reaction solution was $0.85 \mathrm{~m} /$ after the addition of $500 \mathrm{KIU}$ of Trasylol and incubated for three days (final dilution of absorbed antiserum was $1: 850,000)$. Bound and free hormone were separated by precipitation with rabbit anti-guinea pig gamma globulin prepared in our laboratory after the addition of $0.1 \mathrm{~m} l$ of diluted normal guinea pig serum $(1: 200)$. After centrifugation at $5^{\circ} \mathrm{C}$ for twenty minutes at 2,500 rpm, the supernatant was decanted and the precipitate counted in an automatic gammaspectrometer. The result of each assay was expressed as the percentage of total radioactivity found in the precipitate.

The talc treated porcine serum was prepared according to Yalow's suggestion (1972) and was added to the standard tubes to equalize non-specific inhibition. Talc powder $(25 \mathrm{gm})$ was added to $100 \mathrm{ml}$ of porcine serum and gently stirred $30 \mathrm{~min}$ at room temperature and over night at $5^{\circ} \mathrm{C}$. The supernatant was collected and stored in small aliquots at $-18^{\circ} \mathrm{C}$ after being centrifuged $30 \mathrm{~min}$ at $10,000 \mathrm{rpm}$ at $5^{\circ} \mathrm{C}$.

Porcine proinsulin (Lot. 615-1082B-180-C), porcine proinsulin C-peptide analogue (sequence 33-63, Lot. 615-1070B-62) and bovine proinsulin (Lot. 615-1072B-284C) were gifts of Dr. R. E. Chance of the Lilly Laboratories. Porcine insulin (Proinsulin free, PJ 5589) and porcine glucagon (Lot. GLF 599A) were given by Dr. W. N. Shaw of the Lilly Laboratories. Both the porcine proinsulin (Lot. 1.6.70) and the bovine proinsulin (Lot. 17.3.70) were kindly supplied by Dr. J. Schlichtkrull of the Novo Research Institute. The synthetic 62-formyllysine porcine proinsulin sequence 31-63 (Yanaihara et al., 1970) was gift of Dr. N. Yanaihara of the Shizuoka College of pharmacy (Shizuoka, Japan). These gifts were 
used for comparison of their immunological activities with our preparations and in cross-reaction studies made in the assays.

CPR and insulin levels of 3 young fasted pigs were assayed by specific radioimmunoassay methods after glucose load $(0.75 \mathrm{~g} / \mathrm{kg} \mathrm{iv})$.

\section{Results}

All of the antisera prepared in guinea pigs showed strong precipitating bands with both porcine proinsulin and porcine insulin by the micro double-diffusion agar precipitin technique (Crowle, 1958). Results of the absorption of antiserum with polymerized porcine insulin and crystalline porcine insulin are shown in Figure 1. Nearly complete removal of cross-reacting insulin antibodies were observed by absorption of the antiserum with crystalline porcine insulin at a ratio of $6.6 \mathrm{mg}$ of insulin per $\mathrm{m} l$ of antiserum. This absorbed antiserum was used for the radioimmunoassay of porcine proinsulin.

When an excess of the first antibody was

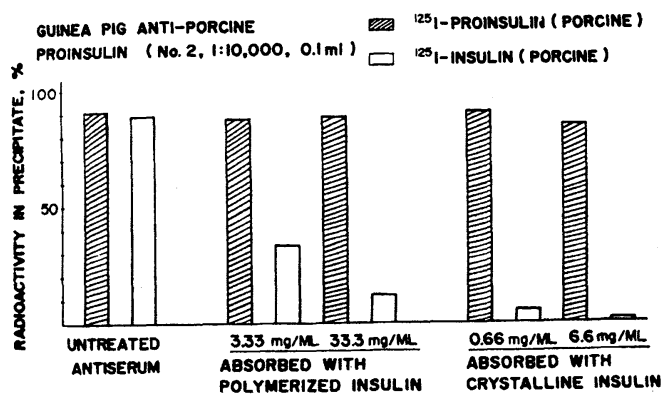

Fig. 1. Effects of absorption of guinea pig antiserum with polymerized or crystalline insulin. $0.1 \mathrm{~m} l$ of diluted antiserum $(1: 10,000)$ was added to tubes containing ${ }^{125} \mathrm{I}$-proinsulin (porcine) or ${ }^{125} \mathrm{I}$-insulin (porcine, $10,000 \mathrm{cpm}$ ) and incubated 3 days at $5^{\circ} \mathrm{C}$. Rabbit anti-guinea pig gamma globulin and carrier normal guinea pig serum (1: 200) were added and incubated overnight at $5^{\circ} \mathrm{C}$. After centrifugations the precipitate was counted and the results expressed as the percentage of total radioactivity found in the precipitate. Almost complete removal of cross-reacting insulin antibodies was achieved after incubation with $6.6 \mathrm{mg}$ of crystalline porcine insulin per $\mathrm{m} l$ of antiserum. added to the assay system, 90 to 91 per cent of the labeled hormone was precipitable after incubation with $0.1 \mathrm{~m} l$ of porcine plasma or talc-treated porcine serum, while 93 to 95 per cent of the labeled hormone was found in the precipitate after incubation without porcine plasma or serum. Furthermore, increasing amounts of rabbit anti-guinea pig gamma globulin or Trasylol had no effects on this inhibition. These results suggest that this inhibitory effect might be due to incubation damage of the labeled hormone by the porcine plasma component or by non-hormonal interference.

Immunological activities of other preparations of porcine proinsulin (Dr. Chance's and Dr. Schlichtkrull's preparation), the synthetic porcine proinsulin C-peptide analogue (Dr. Yanaihara's preparation), and proinsulin free porcine insulin (Lilly, PJ 5589) were compared in the presence of $0.1 \mathrm{~m} l$ of talc-treated porcine serum. A typical dose response line, as shown in Figure 2, was almost identical to dose

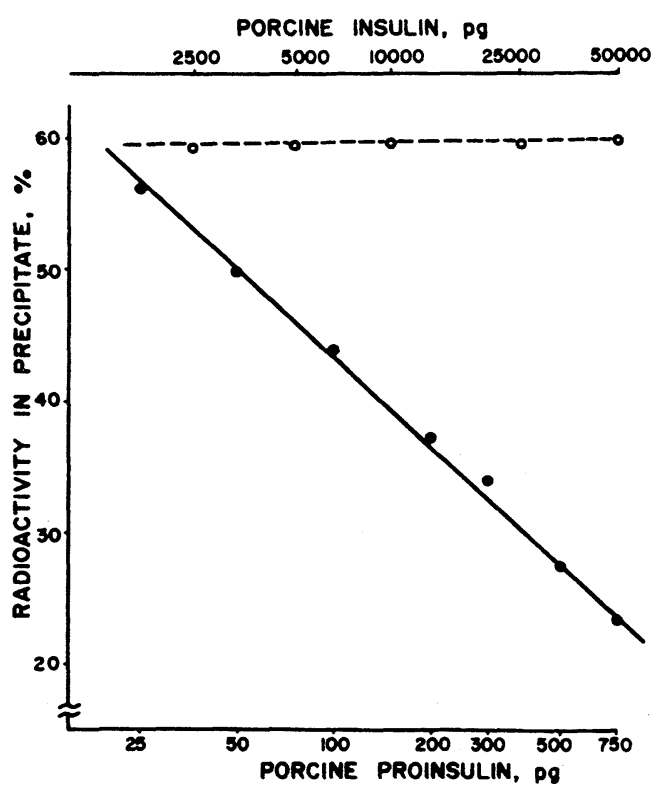

Fig. 2. A typical dose response line of porcine proinsulin on a logarithmic scale. No competition of labeled hormone was noted with $50 \mathrm{ng}$ of porcine insulin. Porcine proinsulin; $\bigcirc-\cdots$ Porcine insulin. 
response lines obtained with isolated porcine proinsulin in our laboratory and with other porcine proinsulin preparations (Dr. Chance's and Dr. Schlichtkrull's porcine proinsulin). No displacement _of labeled hormone was noted in the assays up to $50 \mathrm{ng}$ of porcine insulin (Figure 2). Both of the synthetic porcine proinsulin $\mathrm{C}$-peptide analogue and the extracted porcine proinsulin C-peptide analogue reacted with the absorbed antiserum essentially to the same extent as by porcine proinsulin on a molar basis (Figure 3).

No competition of labeled hormone was observed in the assays up to $50 \mathrm{ng}$ of bovine proinsulin using both Dr. Chance's and Dr. Schlichtkrull's preparations and up to $500 \mathrm{ng}$ of porcine glucagon.

Porcine proinsulin solution of 1, 2 and $3 \mathrm{ng}$ per $\mathrm{ml}$ of talc-treated porcine serum were prepared and recovery of added porcine proinsulin from these talc-treated porcine serum is shown in Figure 4. Almost 100 per cent recovery of added porcine proinsulin was noted from talc-treated porcine serum.

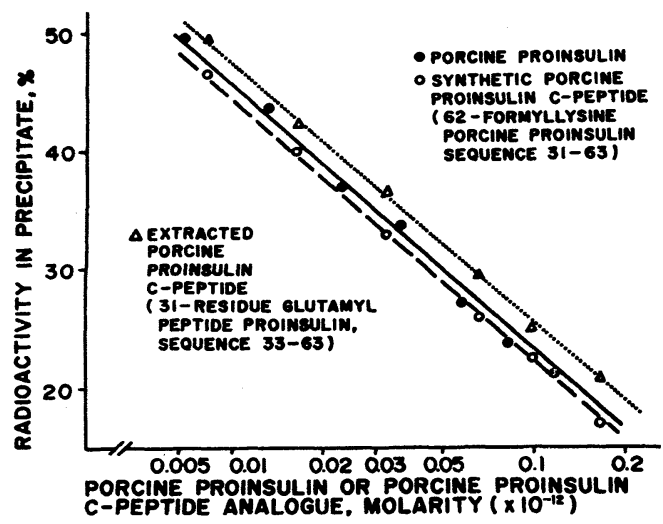

Fig. 3. Typical dose response lines of porcine proinsulin, synthetic porcine proinsulin C-peptide analogue (62-formyllysine porcine proinsulin, sequence 31-63), and extracted porcine proinsulin C-peptide analogue (31-residue glutamyl peptide, sequence 33-63) on a logarithmic scale. All lines run parallel. - Porcine proinsulin; $\bigcirc-$--- Synthetic porcine proinsulin C-peptide analogue; $\triangle \cdots \cdots \triangle$ Extracted porcine proinsulin C-peptide analogue.

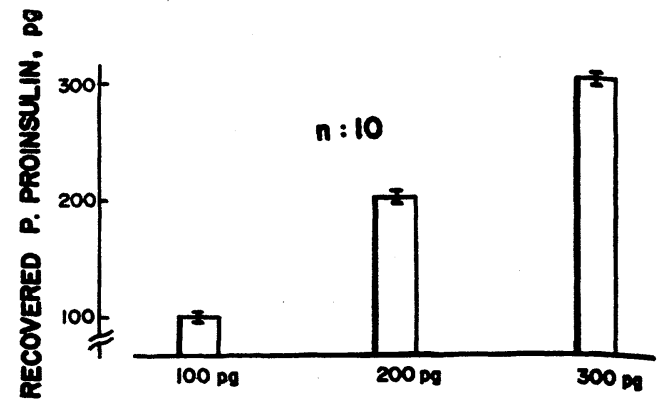

Fig. 4. Recovery test of porcine proinsulin from talc treated porcine serum. Porcine proinsulin were added to talc trated porcine serum at concentrations of $1,000 \mathrm{pg}, 2,000 \mathrm{pg}$ and $3,000 \mathrm{pg}$ per $\mathrm{ml}$, and these samples were assayed for their porcine proinsulin content. Results were as follows: $100 \mathrm{pg}, 101.7 \pm 3.22 \mathrm{pg} ; 200 \mathrm{pg}, 204.2 \pm$ $3.28 \mathrm{pg} ; 300 \mathrm{pg}, 301.4 \pm 5.78 \mathrm{pg}$. (Values represented means SEM).

Moreover, porcine plasma was collected following a glucose tolerance test $(0.75 \mathrm{gm} / \mathrm{kg}$ iv) at $30 \mathrm{~min}$ and several dilutions of this plasma were made with talc-treated porcine serum and gave a linear line which ran parallel to a dose-response line on a logarithmic scale (Figure 5). The coefficient of variance was 6.5 per cent at a level 10 times the sensitivity for the two assays, and the maximum sensitivity of the assay was 20 picogram.

Porcine CPR, insulin, and plasma glucose in unextracted peripheral blood were assayed separately in 3 pigs after intravenous glucose load $(0.75 \mathrm{~g} / \mathrm{kg}$ iv). These results are shown in Table 1. Plasma CPR levels rose to high levels, of 1.65 to $1.95 \mathrm{ng} / \mathrm{m} l$ at $30 \mathrm{~min}$, from low fasting levels of less than 0.2 to $0.4 \mathrm{ng} / \mathrm{m} l$ but appeared to be decreased at $60 \mathrm{~min}$. Also plasma CPR levels appeared to be higher than that of insulin in the pig after glucose load.

\section{Discussion}

Since insulin exists in the proinsulin molecule, proinsulin antiserum may react with insulin. To eliminate cross-reaction with insulin, Sephadex-insulin was employed as 


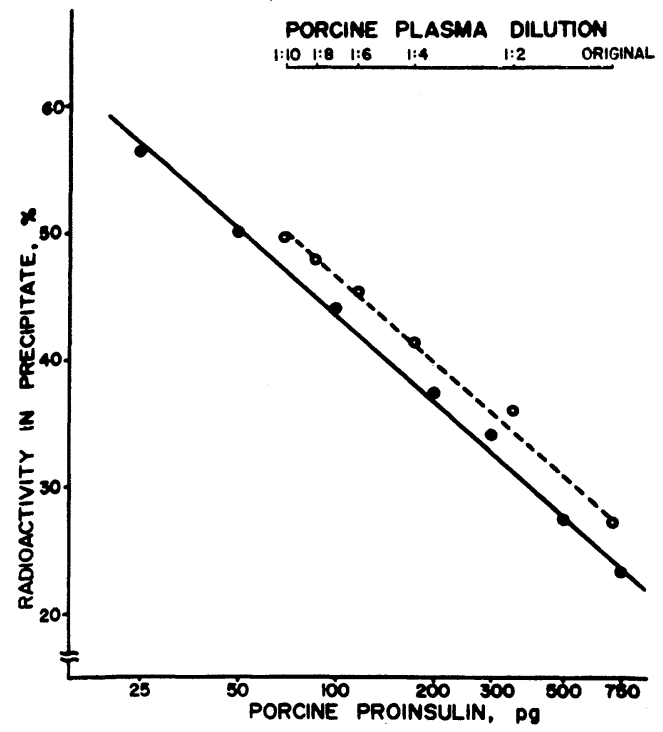

Fig. 5. Porcine plasma was obtained $30 \mathrm{~min}$ after glucose load $(0.75 \mathrm{~g} / \mathrm{kg}$ iv). This plasma was diluted with talc treated porcine serum. Dilutions were $1: 10,1: 8,1: 6,1: 4,1: 2$, and $0.1 \mathrm{ml}$ of each diluted solution was assayed for porcine proinsulin. Both lines run parallel. proinsulin; $\bigcirc--\bigcirc$ Porcine plasma dilutions.

immunosorvent (Yip and Logothetopoulos, 1969). After such treatment, their anti-bovine proinsulin serum retained considerable reactivity toward proinsulin but lost its ability to bind insulin. However, their radioimmunoassay for bovine proinsulin appeared to be unsuitable for measurement of CPR in unextracted peripheral blood. We have utilized polymerized insulin and crystalline insulin for such a purpose, and direct addition of porcine insulin to antiserum appears to be effective for the removal of cross-reacting insulin antibodies. As shown in Figure 1, addition of $6.6 \mathrm{mg}$ of porcine insulin per $\mathrm{m} l$ of antiserum completely removed such cross-reacting antibodies. Coexistence with a $50 \mathrm{ng}$ of porcine insulin does not affect the radioimmunoassay of porcine proinsulin with absorbed antiserum. Rubenstein et al., (1970) reported that removal of the antibodies directed against insulin yields an antiserum which binds proinsulin as well as C-peptide. Both of the synthetic porcine proinsulin $\mathrm{C}$-peptide and extracted porcine proinsulin C-peptide analogue competed with the tracer for binding to anti-synthetic porcine proinsulin C-peptide sera to the same extent as by porcine proinsulin on a molar basis (Yanaihara et al., 1972). Synthetic and extracted porcine proinsulin C-peptide as well as porcine proinsulin reacted in the same way to our absorbed anti-porcine proinsulin serum. The "coated proinsulin antibody" of Rubenstein et al., (1968) was employed to remove insulin antibodies and removal of insulin antibodies was achieved (Stoll et al., 1970). But sensitivity of their assay appeared inadequate for determination of unextracted plasma levels of

Table 1. Porcine CPR and insulin response to iv glucose load in 3 pigs $(0.75 \mathrm{~g} / \mathrm{kg})$

\begin{tabular}{cllccc} 
& & & Fasting & $30 \mathrm{~min}$ & $60 \mathrm{~min}$ \\
\hline \multirow{2}{*}{ Pig No. 1. } & CPR, & $\mathrm{ng} / \mathrm{m} l$ & $\mathrm{ND}^{*}$ & 1.96 & ND $^{*}$ \\
& Insulin, & $\mathrm{ng} / \mathrm{m} l$ & $\mathrm{ND}^{* *}$ & 0.39 & $\mathrm{ND}^{* *}$ \\
& Glusose, & $\mathrm{mg} \%$ & 72 & 174 & 102 \\
& CPR, & $\mathrm{ng} / \mathrm{m} l$ & $\mathrm{ND}^{*}$ & 1.65 & 0.95 \\
& Insulin, & $\mathrm{ng} / \mathrm{m} l$ & 0.09 & 0.5 & 0.18 \\
Pig No. 2. & Glucose, & $\mathrm{mg} \%$ & 82 & 155 & 122 \\
& CPR, 3. & $\mathrm{ng} / \mathrm{m} l$ & 0.4 & 1.8 & 0.98 \\
& Insulin, & $\mathrm{ng} / \mathrm{m} l$ & $\mathrm{ND}^{* *}$ & 0.18 & 0.11 \\
& Glucose, & $\mathrm{mg} \%$ & 120 & 300 & 152 \\
\hline
\end{tabular}

Porcine CPR and insulin levels in unextracted peripheral blood were measured by the specific radioimmunoassay separately. ND* Less than $0.2 \mathrm{ng} / \mathrm{m} /$ for porcine CPR; ND** Less than $0.09 \mathrm{ng} / \mathrm{m} l$ for porcine insulin. 
CPR. Recently, utilizing a specific insulin degrading enzyme, measurement of proinsulin in human plasma has been reported (Kitabchi et al., 1971). After the degradation of insulin, proinsulín was assayed against an insulin standard with insulin antibodies. Thus, this is not a specific assay for proinsulin in plasma.

Plasma CPR rose rapidly in response to hyperglycemia in 3 pigs and these results resemble those of Melani's (1970b) obese human subjects and reported results of healthy human subjects (Block et al., 1972b). They stated that after oral glucose load, CPR levels tend to rise in a similar manner to that of insulin, and our results support these findings.

Porcine proinsulin intermediate forms may react with antiserum used in these studies as well as porcine proinsulin or C-peptide. This may partly account for the high plasma levels of CPR in the pigs. The method described here appears to be suitable for the measurement of porcine CPR in unextracted peripheral blood.

\section{Acknowledgment}

We are grateful to Doctors R. E. Chance, W. N. Shaw, J. Schlichtkrull and N. Yanaihara for their generous gifts of porcine, bovine proinsulin, extracted porcine proinsulin C-peptide analogue, porcine insulin, glucagon, and synthetic porcine proinsulin $\mathrm{C}$-peptide analogue. The authors wish to express their appreciation to Dr. S. Ueda and Professors S. Miwa and S. Shibata for their interest and valuable suggestions. We also thank Miss J. Hamada for her skillful technical assistance.

\section{References}

Avarameas, S. (1969). Immunochemistry 6, 43. Block, M. B., M. E. Mako, D. F. Steiner and A. H. Rubenstein (1972a). J. Clin. Endocr. 35, 402 .

Block, M. B., M. E. Mako, D. F. Steiner, and

A. H. Rubenstein (1972b). Diabetes 21, 1013.

Chance, R. E., R. M. Ellis and W. W. Bromer
(1967). Science 161, 165.

Chance, R. E. (1972). Diabetes 21 (Suppl. 2), 461.

Growle, A. J. (1958). J. Lab. and Clin. Med. 52, 784.

Grant, P. T. (1971). Biochem. J. 125, 49p (Abstract).

Horino, M., K. Kobayashi and K. Ariyoshi (1972). Endocrinol. Japon. 19, 579.

Hunter, W. M. and F. C. Greenwood (1962). Nature 194, 495.

Kitabchi, A., W. C. Duchworth, J. S. Bruch and M. Heineman (1971). J. Clin. Invest. 50, 1792.

Melani, F., A. H. Rubenstein, P. E. Oyer and D. F. Steiner (1970a). Proc. Nat. Acad. Sci. USA 67, 148.

Melani, F., A. H. Rubenstein and D. F. Steiner (1970b). J. Clin. Invest. 49, 497.

Morgan, C. R. and A. Lazarow (1963). Diabetes 12, 115.

Rubenstein, A. H., S. Cho and D. F. Steiner (1968). Lancet 1, 1353.

Rubenstein, A. H., W. P. Welbourne, M. Mako, F. Melani and D. F. Steiner (1970). Diabetes 19, 546.

Sorenson, R. L., M. W. Steffes and R. W. Lindall (1970). Endocrinology 86, 88.

Steiner, D. F. and P. E. Oyer (1967). Proc. Nat. Acad. Sci. USA 57, 473.

Steiner, D. F., D. Cunningham, L. Spigelman and B. Aten (1967). Science 157, 697.

Stoll, R. W., J. L. Touber, L. A. Menahn and R. H. Williams (1970). Proc. Soc. Exp. Biol. Med. 133, 894.

Yalow, R. S. (1972). Saishin Igaku 27, 1220. (In Japanese)

Yanaihara, N., T. Hashimoto, C. Yanaihara and N. Sakura (1970). Chem. Pharm. Bull. (Tokyo) 18, 417.

Yanaihara, N., T. Hashimoto, C. Yanaihara, M. Sakagami and N. Sakura (1972). Diabetes 21 (Suppl. 2), 476.

Yip, C. C. and B. J. Lin (1967). Biochem. Biophys. Res. Comm. 29, 384.

Yip, C. C. and J. Logothetopoulos (1969). Proc. Nat. Acad. Sci. USA 62, 415. 